\title{
STUDIES ON THE PERIPHERAL RELATIONS OF THE MUSCULUS DILATATOR PUPILLAE*
}

\author{
BY \\ Prosector O. Berner, M.D. \\ COMMUNICATION FROM THE ANATOMICAL INSTITUTE OF THE UNIVERSITY \\ OF OSLO, NORWAY
}

THE periphery of the iris proves to be a region of the human body whose anatomical conditions have not as yet been properly examined. I got a suspicion of this fact when I was engaged on my examinations of the eyes of some individuals belonging to a family in which miosis congenita occurs. + Since my studies of the miosis were brought to a close, I have examined a great number of eyes which had all been removed by enucleation because of a choroidal tumour, but where the pressure had not increased, for the purpose of studying more particularly the periphery of the iris in the normal eye. The eyes were fixed immediately after the operation, in 10 per cent. formalin, in Zenker's fluid or in formalinsublimate, and the tumour in the eyes employed did not extend so far forward as to involve the iris. I was supplied with this valuable material by a number of Norwegian, Swedish, and Finnish colleagues.

To begin with I was chiefly interested in finding out the nature of the fixed attachment of the musculus dilatator pupillae, whether this muscle had a "punctum fixum" like other muscles, and where this fixed attachment was eventually to be found. In the last case of miosis congenita I had found appearances that I had interpreted as imperfect rudiments of what I called "anchoring-points" for the dilatator muscle. In the literature treating on the dilatator muscle, Faber is the only one, as far as I can see, who speaks of a "punctum fixatum," and he places the fixed attachment of the dilatator in the walls of the veins of the periphery of the iris. Juler and Huttenbrenner had already described filaments running from the dilatator up to the pectinate ligament, at the time when v. Szily once more described filaments, extending not only up to the pectinate ligament, but right up to the ciliary muscle as well, and characterized these filaments as the "ciliary insertion" of the dilatator. Forsmark says about these filaments to the pectinate ligament and the ciliary muscle dass sie zweifelsohne selten sind, denn ich habe in meinen Praeparaten kein einziges gefunden.

The other works, even the leading works, on the dilatator muscle, contain little or nothing about the attachment of this

${ }^{*}$ Received November, 1925.

†See Holth and Berner in this Journal (Brit. Jl. of Ophthal., p. 401, 1923.) 
peculiar muscle. The explanation of this fact can be found only in the extraordinary interest with which was discussed the muchdebated question : whether the iris has or has not its own dilatator muscle. During this discussion attention was paid only to the main question, and all details were thrown into the background. Thus Grynfellt and Heerfordt say that the dilatator begins where the epithelium of the iris joins the epithelium of the ciliary body, and though Forsmark has mentioned filaments radiating into the connective tissue of the ciliary body, he does not attach much importance to them. It remains to be said that Grunert had already described such filaments in 1898. Grunert's work is of merit, not only because he was the first to take full advantage of the methods of depigmentation, but also because in his examination he has made use of surface sections and not merely the ordinary radial sections. Grunert considers these filaments in the ciliary body as the fixed attachments of the dilatator muscle. Surface sections have been used by Forsmark as well, but he complained of the series having become defective because of the depigmentation (Alfieri's method).

Already during the seventies, Merkel, Iwanoff, and Jeropheff had drawn attention to and illustrated the peculiar circular bending made by the dilatator fibres in the periphery of the iris. In Merkel's work in 1873 there is found a fine drawing of this.

These things, however, are not described particularly enough in the main works. Thus Heerfordt states that the muscular cells suddenly bend in a circular direction at the ciliary border, without this carrying with it any thickening of the muscle-quite the contrary. I cannot see that Grynfellt describes any change in the direction of the elements at the ciliary border. This is done, however, both by Grunert and Forsmark. Grunert has seen some of the cells bending in a circular direction and forming arcades, while others continued their radial course. His description and illustration are however incomplete. He points out that the periphery of the dilatator is thickened. Forsmark is the one who has studied most closely the conditions of the periphery. His description of it shows that he too has seen in most cases that the dilatator gradually ceases at the base of the iris. Meanwhile, the part of the cell containing the nucleus changes its shape, being stretched laterally, while the nucleus is placed tangentially. This implies a change from radial to circular direction. Forsmark, however, has often seen that this regular course is changed in the depressions between the ciliary processes, and that more complicated conditions occur. To begin with, the fibrillar layer is swollen, as he believes owing. generally, to a change of shape caused by pressure. But in other cases the swelling is owing to the existence of muscle cells of the mesodermal type. This kind 
of swelling he has found in all the specimens that he has examined from adult persons as well as from children, although the frequency and the extent have varied much. The thickening evidently has something to do with the "strengthening bands" (that also consist of cells of the mesodermal type), and when these approach the periphery of the iris, the muscle cells pass into a circular direction, only some of them retaining the original radial position. Only in exceptional cases he found bundles which had kept their original radial direction and that went beyond the border of the iris.

This short summary as to the periphery of the dilatator muscle was all that I was able to find in the literature, when during the revision of the second case of miosis congenita familiaris I was aware that our knowledge of this region of the human anatomy is very defective.

I began this work believing that in the way in which I carried out the depigmentation I was particularly qualified to succeed in the solution of my problem, because after the depigmentation of the material in toto I was able to imbed it in paraffin and to cut long series of it without losing a single section. The fact is that this is generally not obtained by depigmenting the ordinary sections in potassium permanganate, because the sections may easily come loose from the slides. At that time I was ignorant of Dr. Mawas' method of depigmenting with chromic acid, a mode of procedure that is much to be preferred to bleaching in potassium permanganate. While engaged in this work I have realized, however, that for the purposes now in question it is preferable not to depigment the material. The fact is that the filaments from the dilatator are pigmented, and they differ greatly from the nonpigmented, smooth musculature in the ciliary muscle, a fact which may be of great importance.

My work would certainly not have given remarkable results if I had not examined surface-sections through the iris and the ciliary body, and I cannot therefore emphasize sufficiently the importance of these surface-sections. The way in which I proceeded was after the fixation to loosen the ciliary body and the iris from the sclera and then to harden the preparation for some time in graduated alcohol until the iris had grown stiff. After a few days I cut through the iris and the ciliary body, with some fine scissors, from the pupil and right out, and thus I divided the preparation into a convenient number of sections. Then, cautiously, I imbedded these sections in paraffin, and through a little handiness and care the curling of the iris may be avoided. I have thus several series of sections including everything from the pupillary border and right out to the ciliary body, so that in the same section one has a view of the iris as well as of the ciliary body. As regards the 
methods of staining, I have employed, in addition to the usual methods, the specific stains for connective tissue, such as we have in Mallory's stain, and in Heidenhain's stain with azan. Unfortunately we do not possess a specific stain for smooth-muscle cells. When the question, as so often happened to me during this work, has been to decide whether a single cell or a little group of cells are smooth-muscle cells or cells of connective tissue, this problem cannot be solved in a better way than by trying to stain the myoglia fibrils.

These come out very well in material fixed, as indicated by Benda, in potassium bichromate, nitric acid, or in Zenker's fluid, and afterwards stained with crystal-violet. This method is rather complicated and I have preferred to use Heidenhain's stain, whereby the coarse fibrils appear very distinctly. It must, however, be observed that with a good fixation and staining with Heidenhain's haematoxylin, nerves and elastic fibres will come out as well. Consequently there may come out in the connective tissue some fibrils that one does not always know how to explain. I have therefore stained each series with its special staining and compared the series inter se. As regards the azan method I wish to point out that in material fixed in Zenker's fluid, and perhaps especially in material fixed in sublimate-formalin, I have obtained very clear pictures of the fibrils in the smooth musculature. As for the elastic tissue, I have stained according to Weigert's original plan as well as according to Hornowsky's method, and I have obtained good pictures. I consider that the elastic tissue found in the immediate vicinity of the angle of the chamber is of a type that differs from other elastic tissue. The fact is that I have had to stain the sections of the iris for a longer time and with a stronger concentration than was necessary for the control-material (arteries fixed in formalin).

With regard to my results I will begin by pointing out that the description of the periphery of the dilatator muscle, given by Grynfellt and Heerfordt, is not correct. According to these writers, the dilatator begins at the spot in which the epithelium of the iris joins the epithelium on the ciliary processes. Neither of these two investigators has noticed that the peripheral part of the dilatator muscle is nearly always thickened. Heerfordt states distinctly that, if anything, it is thinner than the rest, and Grynfellt points out that this muscle ends both at the pupil and in the periphery en se continuant avec l'epithelium non modifie de la lame myogéne. Grunert, on the other hand, has maintained that the peripheral part of the dilatator muscle is thickened, and he has also seen that it radiates into the connective tissue in the ciliary body. According to my experience, the thickening may be lacking in a single section, but will soon reappear in the series. 

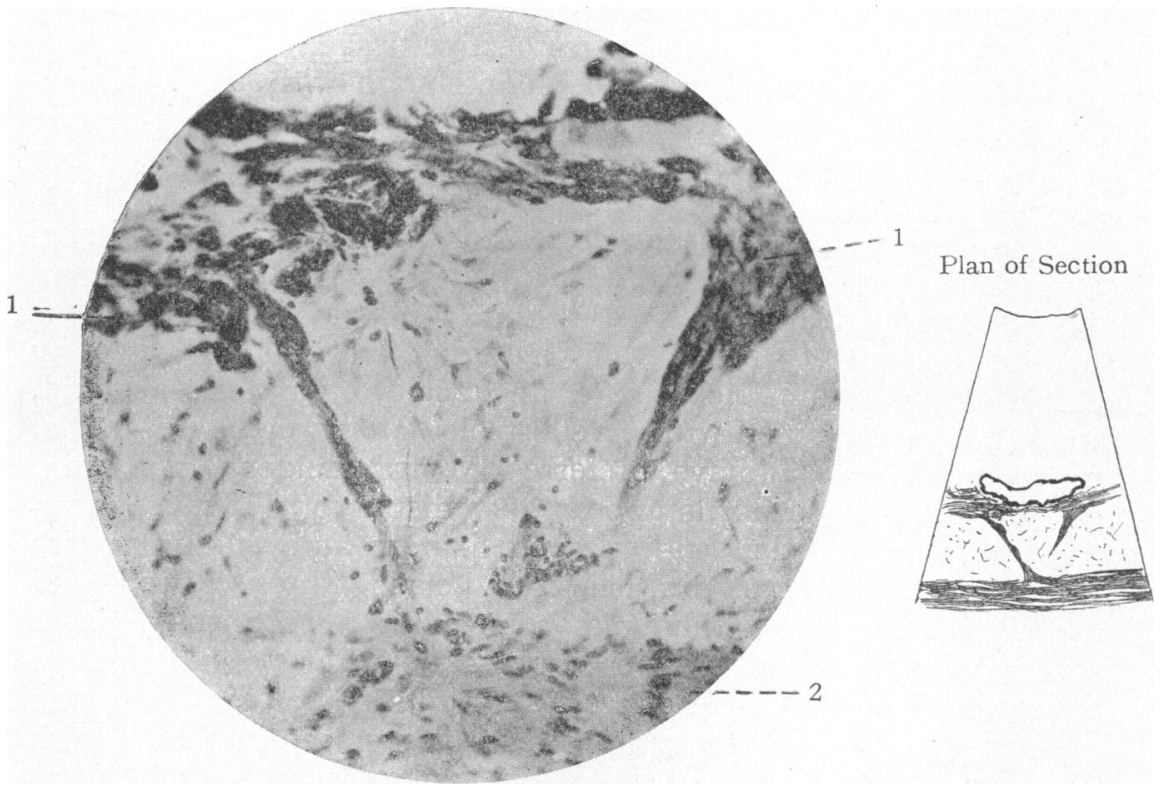

FIG 1.
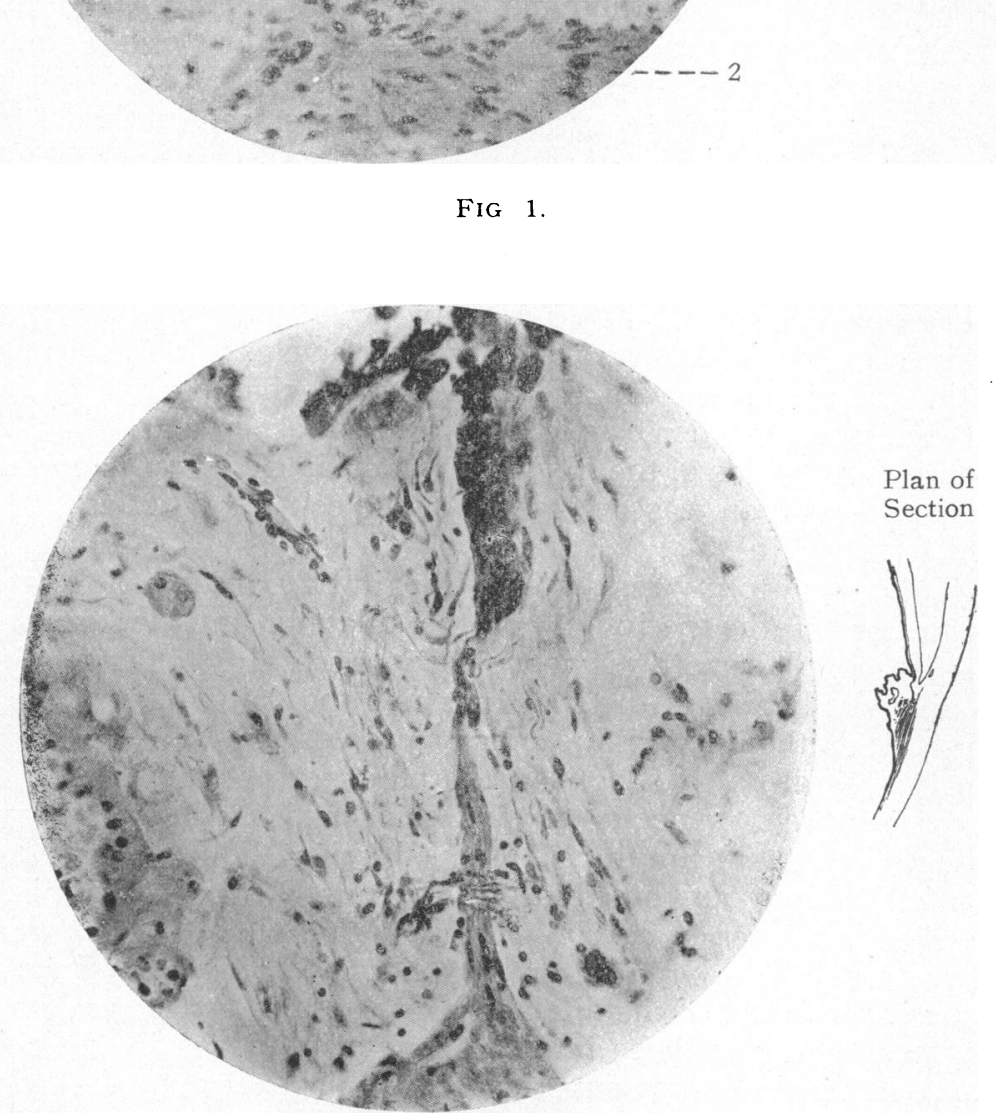

FIG. 2. 
Thus I have constantly found the peripheral part of the dilatator thickened, with the long fillets penetrating into the ciliary body, but, in contrast to Grunert who emphasizes that their direction is "strictly radial," I must draw attention to the oblique direction of their course, as shown in Fig. 1. This oblique course is probably the reason why comparatively few investigators have observed the fillets to the pectinate ligament, as only some of them are seen in the ordinary radial sections. In some cases one may now see in a surface section that the dilatator muscle, through its fillets, is in direct connection with the ciliary muscle. This muscular relation has formerly only been described by v. Szily. What v. Szily has actually seen of these connections is, however, somewhat doubtful, judging from the very outlined drawing he refers to. His material has indeed only consisted of two eyes, and he mentions neither surface sections nor series. From my figure it appears that the direction of the fillets is very oblique and also that the part belonging to the dilatator has pigmented cells, whereas the ciliary muscle is non-pigmented. It is no doubt this oblique direction of the fillets which is the cause of these fillets being very seldom seen in ordinary radial sections. The fact is that in my vast material I have only once seen in the radial sections how the fillet from the dilatator muscle reached up to and merged into the ciliary muscle (Fig. 2).

If one reconstructs these vigorous muscle bridges, from surface sections, graphically, figures will come out similar to those shown in Figs. 3 and 4.

I believe, however, the development of large muscular connections between the two muscles, as seen in Fig. 1, to be comparatively rare. In my material, consisting of about 20 eyes, I have only seen them twice. The shape that the dilatator muscle generally takes in the periphery of the iris is that the thickened rough margin has filaments which extend obliquely towards the ciliary body, but do not reach quite up to the ciliary muscle. The reconstructions also convey an impression of these filaments. Sometimes they divide into single smooth-muscle cells that advance into the connective tissue and may be traced as single cells some distance into the loose tissue between the iris and the ciliary body (Fig. 5). Sometimes, however, the muscle fillet is surrounded with a mantle of connective tissue which is continued outward in the periphery and actually has the appearance of a tendon. In other cases the connective tissue is not so definite that there can be a question of a tendon, but the fine fibres of connective tissue that in these cases extend from the filaments of the periphery of the dilatator in the direction of the ciliary body all produce the same effect (Fig. 6). Some of these fibres attach themselves to the pectinate ligament in the way described by v. Szily and others, 


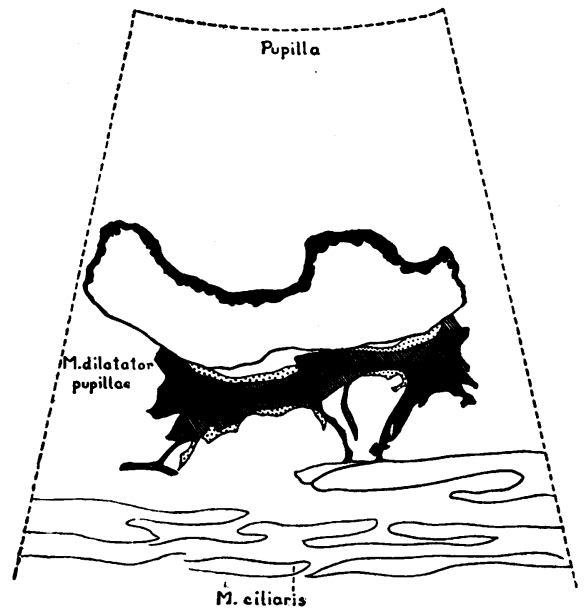

FIG. 3.

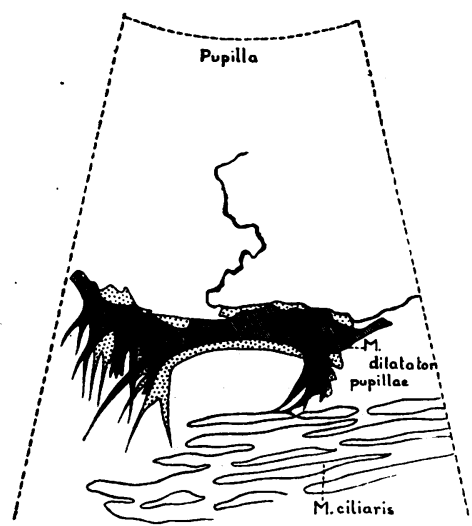

FIG. 4.

Graphic reconstruction of 4 consecutive sections of the series through the periphery of the dilatator muscle, showing the connections between it and the ciliary muscle.

and as shown by me in Fig. 7. If these connections have so far only been described by a few investigators it is no doubt, as mentioned, because the filaments as a rule take a very oblique course (one may say a tangential direction in relation to the periphery of the iris), and consequently they are not to be seen in an ordinary radial section. That my statement is correct is quite apparent; I think, from the surface section, Fig. 6 (see the filaments furthest to the right). 

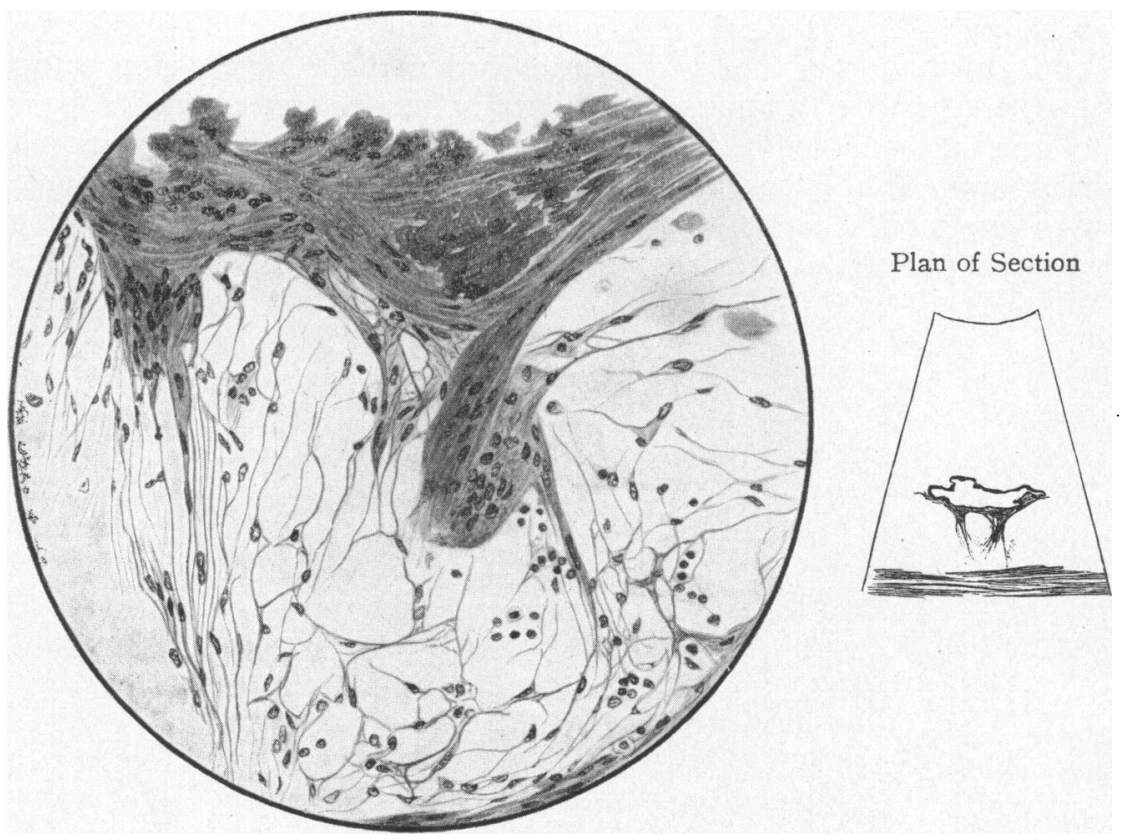

FIG. 5.
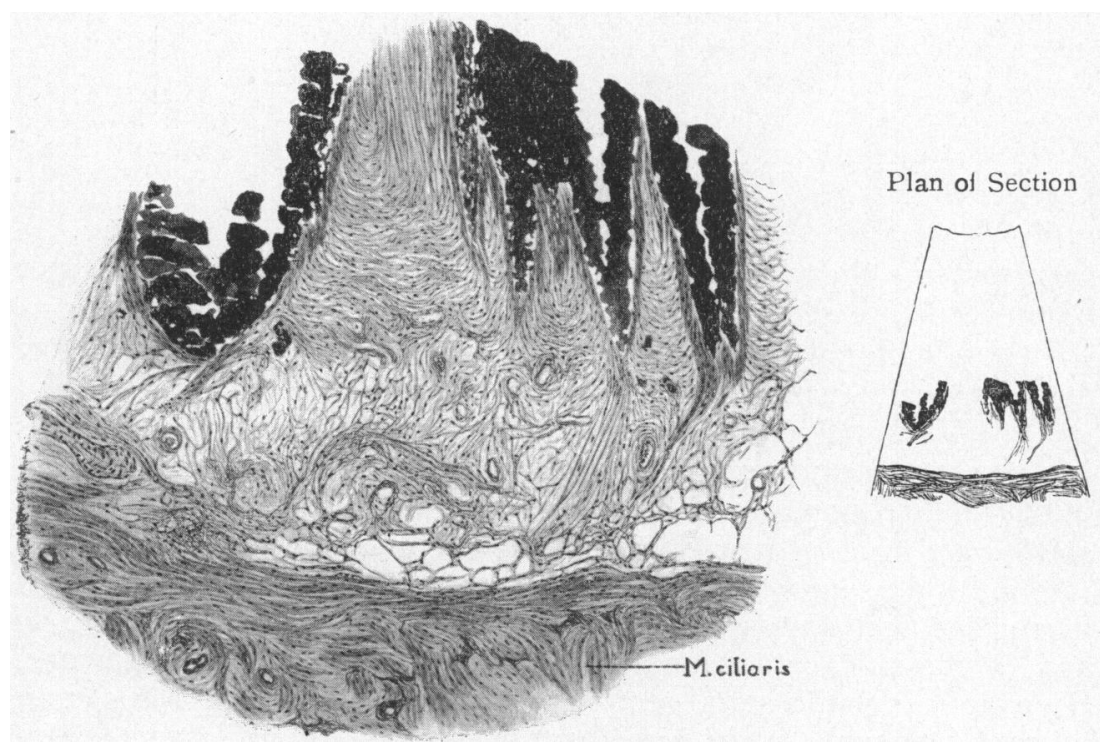

FIG. 6. 
If the above description of the periphery of the iris is compared with the descriptions found in the current textbooks of anatomy and ophthalmology, a great difference will be seen. According to the usual descriptions, the dilatator muscle ceases at the base of the iris, and only some few investigators have seen occasional filaments. Forsmark, for example, considers them as exceptions. My experience is, however, that these filaments form part of the normal picture of the periphery of the iris, and, if the previous

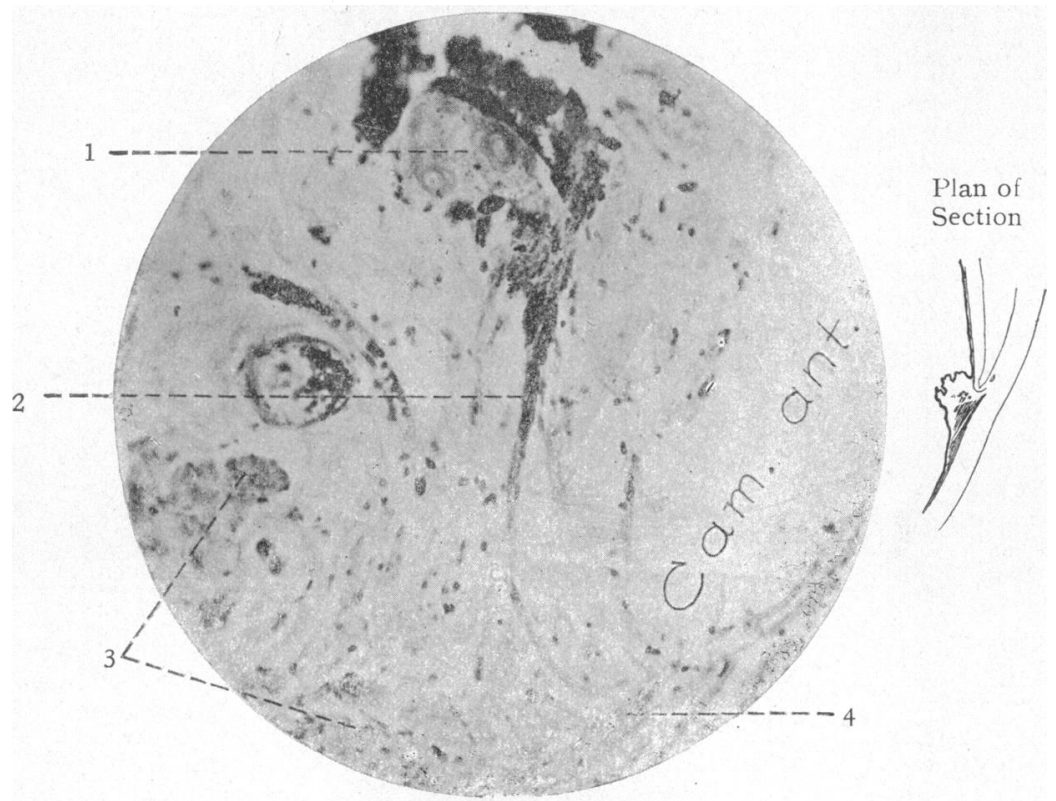

FIG. 7.

investigators have not seen them, it is because they have not studied surface sections.

In my material, however, I have examined an iris from a girl aged 14 years, which was not quite in accordance with the usual picture. In the many series I had of radial sections from this iris, I never found any prolongation of the dilatator muscle in an outward direction, nor was there any swelling of its periphery, similar to what is nearly always found in a normal iris, at any rate if a sufficiently long series is examined. Neither in my series of surface sections were there found pictures quite answering to any of the surface sections that I have reproduced in this work. By examining thin serial sections (surface sections) from this case, I have, however, made sure that in this case also filaments were found from the dilatator muscle traceable out into the loose con- 
nective tissue near the angle of the chamber, but they consisted almost entirely of single cells, and only in rare cases of small groups. It must also be observed that the radiating muscle cells nearly always were running very tangentially, and this explains fully why they were not seen in the radial sections. The radial sections from this case were of interest also because it seemed that the muscle of Müller was absent. This, however, proved not to be the case in the surface sections.

The distinct muscular connections that I have found between the dilatator muscle and the ciliary muscle have caused me to examine also the structure of the ciliary muscle. This is all the more natural because the views of the writers as to the structure of this muscle are rather varied. My examinations of the structure of this muscle have conveyed to me the impression that the last word concerning this muscle has not yet been pronounced. A correct view of the structure of this complicated muscle is no doubt only to be had on the base of reconstructions (graphic or plastic). Such I have not yet attempted, however, and on this occasion I confine myself to making some supplementary remarks about this peculiar muscle.

Most authors describe three directions of the course of the muscular bundles in the ciliary muscle, viz., the "meridional," the "circular," and the "radial" or, as called by others, the "oblique" bundles. With regard to the last, I think that the designation "oblique" must be preferable to "radial." The fact is that these bundles run in the direction from the front (from the sclera) backwards and inwards to the so-called "interior plate" of the ciliary body. Salzmann describes this muscle as a network of bundles that are connected with each other. About the bundles running in an oblique direction he says that they have no end, denn das Gerüst laüft in sich selbst zurück. 'The circular part is also described by Salzmann as part of the network and not as einen selbständigen, von den radialen Portion unabhängigen Anteil. Szymonowicz speaks about the muscular bundles forming a muscle ring. Schaffer states concerning them that they have an absolutely circular course. Holmgren says that they form "an independent part" of the ciliary muscle. And Rauber-Kopsch says about them that von Anfang they have a circular course.

Mawas gives a quite different description of the ciliary muscle. In the first place it must be remembered, he says, that the shape of this muscle varies enormously, not only with increasing years, but also individually. The shape may vary from one section to the other. He describes meridional fibres, extending from the ora serrata forwards, by the name of longitudinal fibres, adding that in some eyes are found in addition fibres of an oblique course. As regards the circular ones he says: "Nous n'avons jamais 
observé de veritables fibres circulaircs. Les quelques rares faisceaux coupés transversalement, au'on observe souvent sur les coupes, représentent à n'en point douter la section des faisceaux obliques."

Nont of these writers are seen to base their views on the study of surface sections. Their judgment of the direction of the fibres is supported only by the appearance of the nucleus in the muscle cell. If the muscle cell is cut longitudinally, the characteristic long rod-shaped nucleus must appear; if the cell is cut across, a small round, centrally placed nucleus is seen, and if we look at oblique sections, we get pictures forming a transition between these extremes. It is, of course, possible to judge the direction of the muscle bundles from the picture of the nucleus, but it is evident that this method of examination must be inferior to one that permits a view of the whole cell. It is therefore quite obvious that through my surface sections, where the bundles of the muscle of Müller are projected into the design, I am much better qualified to form an opinion on the development and the course of the circular bundles, than if I had confined myself to calculating the conditions from the pictures in ordinary radial sections.

By the references quoted from various writers, it is apparent that the problem which has particularly interested me is that of the condition of the circular fibres. I will state at once that I have arrived at quite another result than that of Dr. Mawas. This investigator denies, as already mentioned, in the most categorical way, the existence of circular fibres. In some human eyes there are only longitudinal fibres, he says, in others oblique fibres may be found, and he believes that these oblique fibres have been taken for circular ones. "En d'autres termes, il ne semble pas exister, chez l'homme, un sphincter ciliaire distinct. Le muscle ciliaire est un muscle annulaire, épaissi en avant, dont les faisceaux constituants ont une direction prédominante antéro-postérieure, arec quelques faisceaux obliques."

My examinations have shown me, however, that muscle bundles running in a circular direction really exist in the ciliary muscle. Their number and development may no doubt change individually, but they always exist, and they are found as a distinct layer which can be traced through several, sometimes many, sections of the series (Fig. 8).

This layer of smooth musculature will most often begin at the top of the series as small and fine bundles, but will increase gradually in order to become, in the most distinct cases, quite large bundles that are all of them running in the same direction, concentrically round the periphery of the iris. When judging of the single section one has of course to consider that the surface section is that of a vaulted organ, whose surface as regards the iris is conical, and this applies to the ciliary muscle too, though the 
surface of the latter is perhaps, to speak more accurately, spherical. The result of this fact will be, with regard to both the organs, that microscopical sections cutting the iris and the ciliary muscle in the plane of the iris, right from the pupil and out into the periphery, must necessarily cut through the organs in such a way that the middle region of the iris and the ciliary muscle respectively, will be lying at a deeper level than the outer margins of the sector. Accordingly, when looking at a section like the one reproduced in

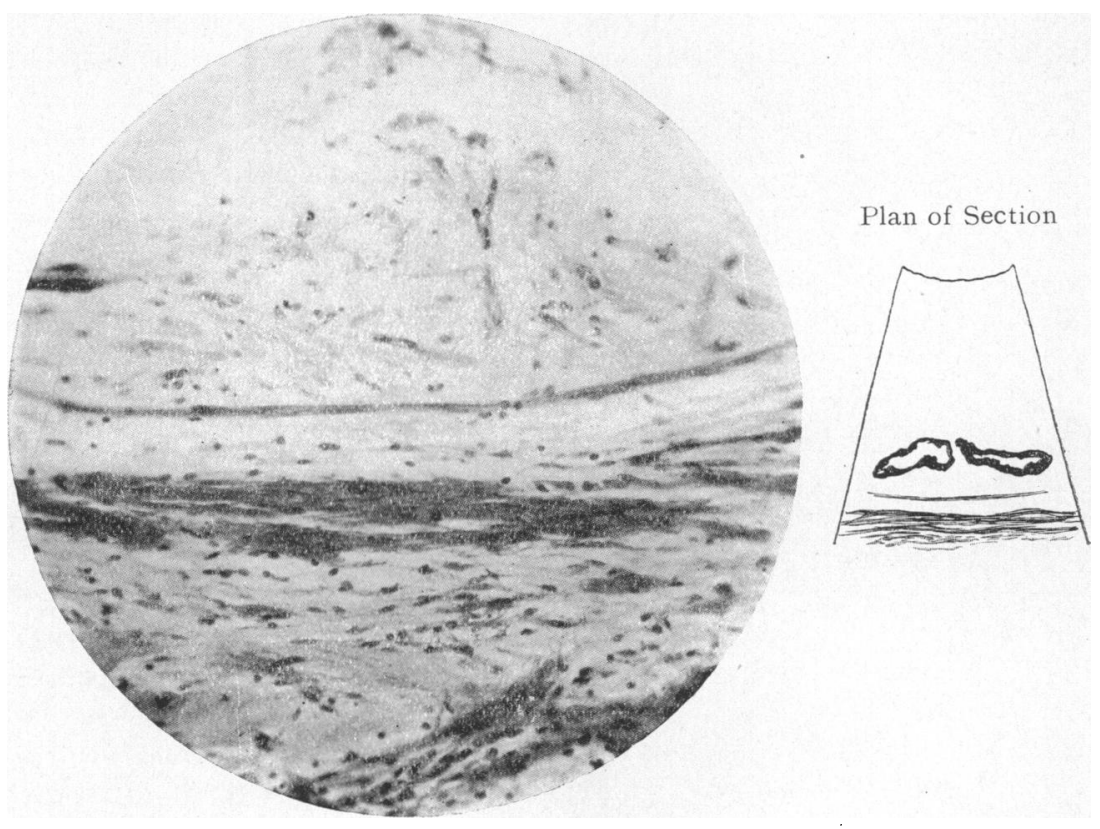

FIG. 8.

Fig. 8, one has to bear in mind that the middle of it represents the conditions deeper down in the ciliary body than do the lateral edges which show us very oblique sections through the bundles round the angle of the chamber. That is why the bundles of concentric, smooth musculature, found in the middle part of the preparation, are coarser than those to be seen towards the outer margins of the section.

Such concentric bundles I have always found in the eyes that I have examined. Therefore I cannot admit that Dr. Mawas is in the right when, in another of his works on the ciliary muscle, he states: "Dans. la même théorie (de Helmholtz), on fait jouer un rôle considérable au muscle circulaire, dit de Müller, muscle qui n'existe pas. . .." The concentric muscle bundles are always found in the ciliary muscle, but I agree that in parts at least they 
are connected with the oblique or so-called radial bundles. 'This connection with the obliquely-running fibres does not prevent them, however, when examined in the right way by means of surface sections, from appearing as a distinct, well-defined part of the ciliary muscle. The arrangement of the muscle bundles in this region is quite in accordance with the structure of any other sphincter muscle consisting of smooth musculature. In order to compare, I have cut sections through the pylorus muscle and have been convinced of this fact.

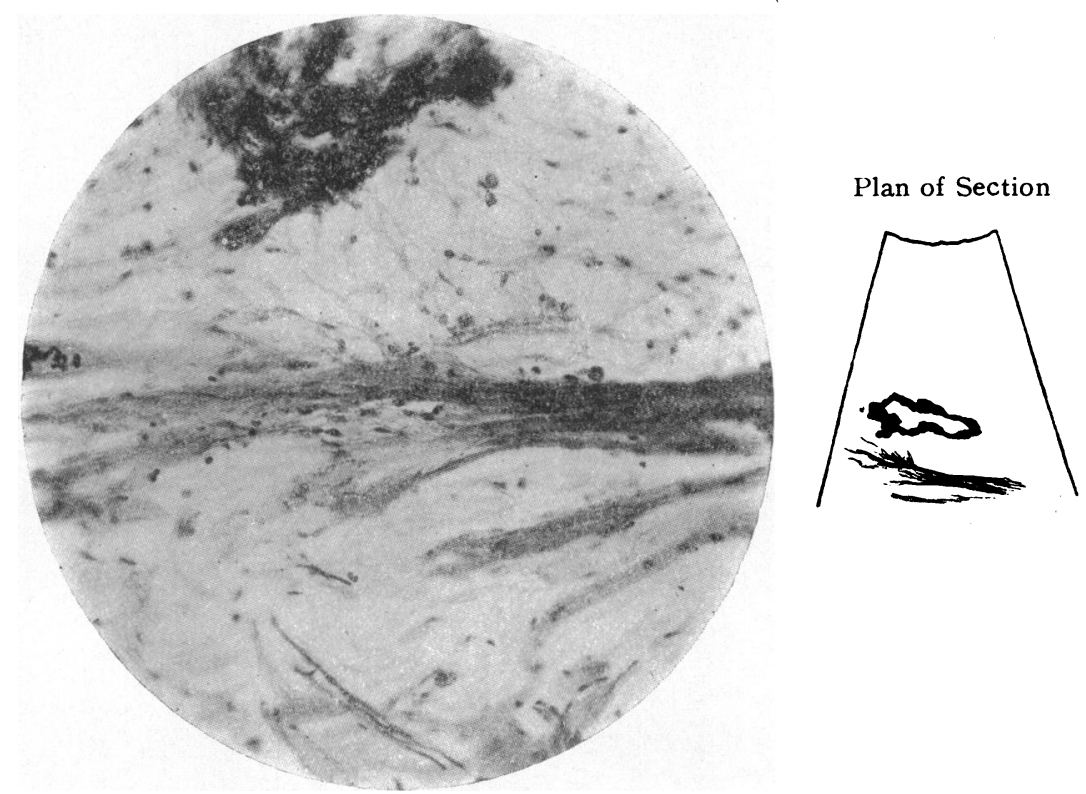

FI G. 9.

These concentric muscle bundles present, however, certain peculiarities with regard to their course, peculiarities that one may suppose are of not a little importance to the physiology of the eye. They are not always found as firm bundles of muscle cells distinctly limited from the surrounding connective tissue. On the contrary, it is seen in the surface sections that the bundles divide into smaller bundles which radiate into the connective tissue; they even dissolve so that the cells radiate into the connective tissue in a way resembling that of the hairs on a brush (Fig. 9). Some of these branchings, sent out from the concentric bundles, take their course inwards to the base of the iris, and it is often possible to make sure that from the top of such a branch a solid bundle of connective tissue extends up to a corresponding filament of the dilatator pupillae. In other cases the bundle dissolves into a group 
of muscle cells which disappear in the lax connective tissue beneath the angle of the chamber. In these last cases it is sometimes hard, on account of the technical difficulties with regard to the specific staining of the smooth muscle cells, to say how far the muscle cells can be traced, just as it is also very difficult to decide whether among the fixed cells of connective tissue there do not occur isolated smooth muscle cells as well. Our want of a sure histological method of solving this problem has led me often to ask myself whether or not a cell with a long, rod-shaped nucleus, lying in the lax connective tissue round the angle of the chamber, was a muscle cell? That in Heidenhain's iron-alum haematoxylin method one has a staining which cannot lead to error, at any rate when there occur several cells together, is a fact accepted by all investigators, I think, even if it cannot safely be relied on relative to a single cell, because by this method, as one knows, other fibres will appear after a good fixation. Therefore I have no doubt that, frequently, quite small bundles of smooth musculature will be found, only consisting of some few cells extending concentrically round the periphery of the iris some way out into this peculiar lax connective tissue.

Yet another fact must be mentioned concerning the structure of the ciliary muscle. If one examines closely ordinary series of radial sections, sometimes pictures are seen which show that the circular muscle bundles dissolve and radiate into the ioose connective tissue at the bottom of the angle of the chamber. In Fig. 10 I reproduce a micro-photograph showing this fact so distinctly that I believe it speaks for itself.

What importance to the physiology of the eye may be attributed to the anatomical conditions found in the periphery of the iris and in the angle of the chamber? Though the details are not yet accurately known, one may no doubt be able to ascertain that the fluid of the chamber has its outlet through the trabecular tissue and Schlemm's canal. Some of the theories of glaucoma indeed look for the cause of the increased intraocular pressure in the complicated outlet through this canal. Arthur Thomson's "pump-action" theory is even directly to the effect that the fluid of the chamber is pumped out of the angle of the chamber by the working of the intraocular muscles on the interior wall of Schlemm's canal. Without venturing in any way to form an opinion as to the bearings of the filaments indicated by me on the genesis of glaucoma, I will point out, however, that their existence is likely to be of no little importance as to the physiological conditions of outlet in the eye. By every contraction of the circular part of the periphery of the dilatator, there will naturally be exerted a tension on the fibres which end in the trabecular tissue, and the pores of the latter must be opened. In 
like manner a contraction of the circular bundles in the ciliary muscle will work on the trabecular tissue through the radiating fibres from the periphery of the iris. I am not only thinking of the displacement of Müller's muscle which is a result of its contraction, nor of the thin, isolated concentric bundles, shown so clearly in Fig. 8, but especially of the radiations from the muscle of Müller of which Fig. 10 represents such a pregnant picture. When my compatriot, Dr. J. G. Raeder, saw this picture, he came to the conclusion that from such anatomical relations between Müller's

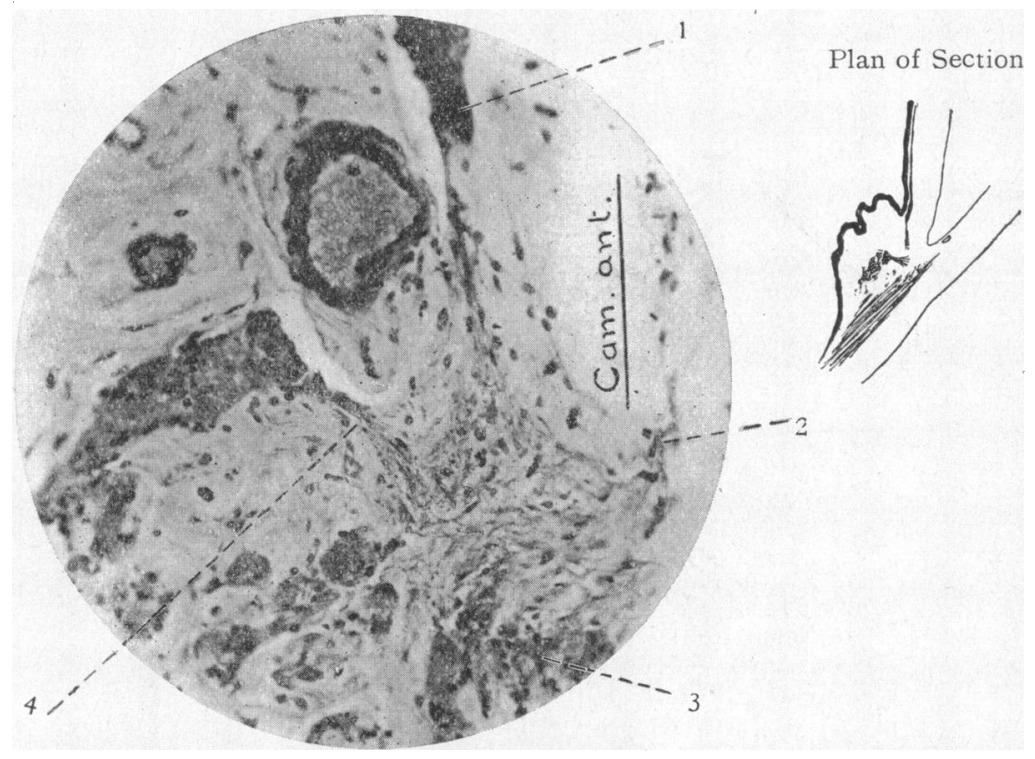

FIG. 10.

muscle and the trabecular tissue there could be deduced an explanation of certain, little noticed, conditions concerning the pressurediminishing effect of eserin in simple glaucoma. Dr. Raeder has methodically measured the intraocular pressure at five-minute intervals after the instillation of eserin, and he has observed that the lowering of the pressure reaches its maximum after about an hour, when the tension begins slowly to increase again. Such a pressure-curve, by its course in proportion to time, recalls the curve of accommodation after the instillation of eserin, but it is not similar to the curve concerning the size of the pupil. The fact. is that the curve of accommodation after the instillation of eserin is already diminishing after an hour, while the miosis remains unchanged for many hours. Consequently, the eserin has a more transitory effect on the ciliary muscle than it has on the sphincter, and as the duration of the pressure lowering effect of eserin (in a 
case of simple glaucoma) answers more closely to the contraction of the ciliary muscle than to the stricture of the pupil, it is not unnatural to attribute a pressure-diminishing effect to the contraction of the ciliary muscle. Dr. Raeder's observation is not published yet, but he has allowed me to quote it, as it is of interest in this connection. The observation made by Professor Grönholm that with some persons the pressure is lower after reading may perhaps be interpreted in the same direction.

\title{
PRINCIPAL REFERENCES
}

Berner, O.- " Relation entre le muscle dilatateur, etc." Comp. rend. Assoc. des Anat., 1925.

Holth and Berner.-"Congenital Miosis, etc," Brit. Jl. of Ophthal., 1923.

Idem. - "Miosis congenita, etc." Videnskapsselskapets Skrifter I, MatNaturv., Klasse, 1922.

Idem. - "Another case of congenital miosis, etc." Videnskapsselskapets Skrifter I, Mat-Naturv., Klasse, 1924.

Forsmark. - "Zur Kenntnis der Irismuskulatur." Mitteilungen aus der Augenklinik d. Carol. medico-chirurg., Inst. Stockholm, 1905,

Grunert.-“Der Dilatator pupillae." Arch. f. Augenheilk., 1898.

Grynfellt. - "Le muscle dilatateur." 1899.

Grönholm. - "Nogra anmärkningar til läran om glaucom." Finska Läkarasälskapets, Handlingar, 1911.

Heerfordt. - "Studien über den Musculus dilatator." Anatom., Hefte, 1900.

Mawas. - " Sur la forme, la direction et le mode d'action du muscle ciliaire." Compt. rend. des Sciences, 1912.

Idem. - "Du rôle du tissue conjonctif du corps ciliaire dans la transmission du muscle ciliaire," Compt. rend. des Sciences, 1913.

Idem.- " Sur un nouveau procédé de décoloration des coupes histologiques." Compt. rend. Soc. Biol., 1913.

v. Szily.- " Beiträge zur Kenntnis der Anatomie und Entwickelungsgeschichte der hinteren Irisschichten." Arch.f. Ophthal., 1902.

\section{NEW FORMED VESSELS IN THE VITREOUS OF SPECIFIC ORIGIN, WITH REPORT OF A CASE WITH DRAWINGS}

BY

\author{
C. A. Clapp, M.D., F.A.C.S.
}

FROM THE DEPARTMENT OF OPHTHALMOLOGY, JOHNS HOPKINS MEDICAL SCHOOL

NEw formed vessels developing in the vitreous have been described frequently in American ophthalmic literature, one of the earliest cases being described by $\mathrm{S}$. Theobald in 188\%, which occurred in a woman, aged 52 years, following a haemorrhage into the vitreous.

Marple in 1901 was fortunate in being able to study such a case ophthalmoscopically and later with the microscope, and again ophthalmoscopically in 1906, when another patient presented herself with vessels extending from the nerve-head $8 \mathrm{D}$. into the vitreous. Both of his cases were in women, the first being 50 years of age and the other 63 . 